ISSN: 2085-0344 (Print)

ISSN: 2503-1864 (Online)

Journal homepage: www.ejournal.almaata.ac.id/literasi

Journal Email: literasi_stia@yahoo.com

\title{
Pendidikan Multikultural dalam Pembelajaran Agama Islam di Sekolah Menegah Atas Negeri (SMAN) 1 Kendawangan Kabupaten Ketapang
}

\author{
Sukino \\ Pascasarjana IAIN Pontianak \\ Email ariefsukino@yahoo.co.id \\ Oktariansyah \\ Prodi PAI FTIK IAIN Pontianak \\ Riyankdw200@gmail.com \\ Erwin \\ Pascasarjana IAIN Pontianak \\ erwinmahrus@gmail.com
}

\begin{abstract}
Senior High School (SMA) is a strategic educational environment in shaping the personality of multicultural students. Through Islamic Religious Education the strategic role of the school is becoming increasingly apparent because Islamic Education that is carried out properly will bring a positive and productive attitude change. The purpose of this study is to investigate multicultural education in SMAN 1 Kendawangan, which is with a lot of diversity. The method used is descriptive qualitative with a phenomenological approach. The results of this study indicate that the first important argumentation of multicultural Islamic religious education in Islamic religious education is the factor, religious religions of ethics, cultural customs, and social status that are often the latent potential of social conflict. Second Multicultural education is carried out by internalizing in an integrated manner through contextualization and Extention of the material, the need for learning strategies, and attitude/behavior-based assessments. Third multicultural education is carried out by incidental (temporary) actions, namely by counseling during the flag ceremony, conducting Friday blessings (healthy and clean schools), and developing tolerance through the momentum of religious holidays in schools.
\end{abstract}

Keywords: Multicultural, Islamic Religious Education, Kendawangan

\begin{abstract}
Abstrak
Sekolah menegah Atas SMA adalah lingkungan Pendidikan yang setrategis dalam pembentukan kepribadian siswa multikuturalis. Melalui Pendidikan Agama Islam peran strategis sekolah tersebut menjadi semakin nyata, karena Pendidikan Agama Islam yang dilaksanakan dengan baik akan membawa perubahan sikap positif dan produktif. Tujuan penelitian ini adalah untuk menginvestigasi Pendidikan multikultural di SMAN 1 Kendawangan, yang merupakan dengan banyak keragaman. Metode yang digunakan adalah deskriptif kualitatif dengan pendekatan fenomenologi. Hasil penelitian ini menunjukkan bahwa pertama argumentasi pentinga Pendidikan agama Islam multicultural dalam Pendidikan agama Islam adalah faktor
\end{abstract}


keragama agama etnis, adat budaya dan status sosial yang sering menjadi potensi laten konflik sosial. Kedua Pendidikan mulitkultural dilakukan dengan menginternalisasikan melalui kontekstualisasi dan pengembangan materi, perluasan strategi pembelajaran dan penilaian berbasis sikap/perilaku. Ketiga pendidkan multikultur secara insidental (temporary) yakni dengan penasihatan pada saat upacara bendera, melakukan jumat berkah (sekolah sehat dan bersih) dan pengembangan toleransi melalui momentum hari besar keagamaan di sekolah.

\section{Kata kunci: Multikultural, Pendidikan Agama Islam, Kendawangan}

\section{PENDAHULUAN}

Perbedaan adalah keniscayaan yang harus diterima oleh setiap orang dalam kehidupannya, karena manusia merupakan makhluk yang memiliki keunikan dan kekhasan. Triandis menjelaskan bahwa keunikan dan kekhasan ini dalam konteks bernegara, berbangsa, dan bermasyarakat akan menimbulkan keberagaman tatanan sosial dan kebudayaan, seperti ditunjukkan oleh Negara Indonesia. Indonesia negara-yang terdiri atas beragam etnis, agama, dan bahasa. Bangsa Indonesia mewarisi kemajemukan suku, ras, dan agama dengan perkembangan sejarahnya masingmasing. Dari segi ras, orang Indonesia setidaknya terdiri dari ras Mongoloid-Melayu (Jawa, Sumatera, Kalimantan, Sulawesi), ras Melanesoid (umumnya Indonesia Timur), dan ras Mongoloid (China). Dari segi etnisitas, Indonesia terdiri atas 556 suku bangsa dan 512 bahasa daerah. Dari segi agama, masyarakat Indonesia memiliki enam agama yang secara sah diakui, yaitu Islam, Kristen, Katolik, Hindu, Buddha, dan Kong $\mathrm{Hu} \mathrm{Cu} .{ }^{1}$.

Pendididikan secara umum merupakan transformasi pengetahuan dan nilai kehidupan serta ketrampilan. Dalam Undang-undang sisdiknas jelas disebutkan bahwa Pendidikan adalah usaha sadar dan terencana untuk mewujudkan suasana belajar dan proses pembelajaran agar peserta didik secara aktif dapat mengembangkan potensi dirinya untuk memIliki kekuatan spiritual agama, pengendalian diri kepribadian, kecerdasan, akhlak

${ }^{1}$ H. C. Triandis and M. J. Gelfland, "Individualism and Collectivism Scale Culture Orientation Scale," Global and Planetary Change, 2017, https://doi. org/10.1016/j.gloplacha.2017.08.018. mulia, serta keterampilan yang diperlukan dirinya, masyarakat, bangsa dan negara. (UU No $20 \mathrm{Thn}$ 2003 Tentang sistem Pendidikan Nasional, pasal 1) ${ }^{2}$.

Keadaan bangsa yang beragam ini sangat membutuhkan pendidikan untuk menanamkan nilai multikulural pada seluruh lapisan masyarakat. Nilai dasar multikultural adalah adanya sikap saling menghargai, menghormati, memahami, dan sikap menerima perbedaan setiap individu. Untuk memiliki sikap saling menghormati dan bertanggung jawab atas dirinya sendiri diperlukan adanya mediator agar nilai nilai yang mendukung eksisitensi multikultur terus bejalan dengan baik. Dan pendidikan itu satu-satunya mediator yang signifikan. Agar semua keragaman yang ada berubah menjadi suatu keindahan dan kebaikan pada semua manusia.

Provinsi Kalimantan Barat merupakan provinsi terbesar ke empat di Indonesia dengan ibukota Pontianak dan terdiri dari 14 kabupaten salah satunya kabupaten Ketapang. Ketapang merupakan salah satu tempat yang paling banyak dikunjungi oleh transmigrasi baik dari penduduk pulau jawa maupun penduduk dari provinsi yang lainnya dikarenakan banyaknya perusahaan-perusahaan yang beroperasi di daerah tersebut. Kabupaten ini memiliki luas wilayah 31.240,74 $\mathrm{km}^{2}$ dan berpenduduk sebesar 427.460 Jiwa (2010). (Https://id.wikipedia.org/ wiki/Kabupaten Ketapang di akses 10 April 2019).

Keberagaman ras dan etnik sudah menjadi hal yang tidak bisa dihindarkan dan

${ }^{2}$ SISDIKNAS, "SISDIKNAS No.20 Tahun 2003 Tentang Sistem Pendidikan Nasional," Zitteliana, 2003. 
ini menimbulkan banyak konflik horizontal dikalangan masyarakat yang masih belum bisa menerima perbedaan yang sangat signifikan. Salah satu contoh kecil terjadi di kecamatan Kendawangan yang merupakan salah satu bagian dari kabupaten Ketapang, penghakiman oleh masa karena berbeda etnis dan suku telah menjadi hal yang sering terlihat walaupun sudah semakin berkurang tiap tahunnya. Contoh nyata yang terjadi di SMAN 1 Kendawangan adalah saat pembullian yang dilakukan oleh siswa-siswa mayoritas kepada siswa minoritas yang berkulit hitam karena berasal dari Flores NTT, cemoohan (bulliying) dilakukan setiap hari membuat siswa tersebut berhenti sekolah. Selain itu, bulliying dengan sasaran bentuk bentuk fisik yang notabene berbeda. Wanita yang tampilan wajah kurang menarik atau jelek menjadi bahan olok-olokan siswi-siswi yang cantik, sehingga menyebabkan siswa lain berhenti, bahkan ada yang nekat ingin bunuh diri karena tidak tahan di bulli. (wawancara dengan siswa tanggal 10 April 2019).

Masalah seperti tersebut di atas tidak hanya tanggung jawab bagi pemerintah tetapi harus di selesaikan oleh seluruh kalangan masyarakat bahkan sampai pada tingkatan pendidikan keluarga. Sekolah yang merupakan tempat terbaik bagi anggota masyarakat yang akan hidup di masyarakat, maka dari itu sekolah harus mampu memberikan pendidikan yang tidak hanya menekankan pada pengetahuan iptek semata tetapi juga berperan aktif dalam menjadikan penerus bangsa yang menghargai perbedaan dan sifat-sifat toleransi. ${ }^{3}$

Aspek yang menjadi kunci dalam pendidikan multkultural di sekolah adalah bagaimana seluruh komponen penyelenggara pendidikan mampu membiasakan diri untuk untuk menghargai perbedaan selera masing-

${ }^{3}$ Jito Subianto, "Peran Keluarga, Sekolah, Dan Masyarakat Dalam Pembentukan Karakter Berkualitas," Edukasia : Jurnal Penelitian Pendidikan Islam, 2013, https://doi.org/10.21043/edukasia.v8i2.757.sehingga menjadi hal yang praktis dan reflektif. Diperlukan sejumlah waktu untuk membuat semua itu menjadi (custom masing individu di sekolah seperti perbedaan selera bermusik, makanan, pakaian, dan hoby. Selebihnya sekolah juga perlu membangun budaya kerja kolaboratif dan membangun sikap demokratis baik dalam proses pembelajaran maupun dalam menyelesakan tugas di luar sekolah. Hal ini sebagaimana penelitian dari banks yang menegaskan bahwa disekolah pembelajaran harus yang adil, yakni bahwa perlakuan dalam pembelajaran harus disampaikan secara adil tanpa membedakan mereka yang berasal dari etnik tertentu, atau dari strata ekonomi tertentu. Dan selanjutnya perlu pemberdayaan budaya sekolah, yakni bahwa lingkungan sekolah sebagai bagian dari kurikulum yang bersifat laten (hidden) harus memberi dukungan terhadap pengembangan dan pembinaan multikulturalisme, baik dalam penyediaan fasilitas belajar, fasilitas ibadah, layanan adminisitrasi dan sebagainya. ${ }^{4}$

Namun kenyataanya masih tergolong sedikit sekolah menegah yang menyadari pentingnya integrasi pendidikan multikultural di sekolah umum. Guru mata pelajaran masih sibuk dengan penyelesaian kompetensi utama mata pelajaran dan berorientasi pada nilai angka semata. Siswa masih dituntut tuntas mata pelajaran jika telah mencapai Kriteria Ketuntasan Minimum (KKM). Proses pembelajaran menjadi kaku dan kurang memperhatikan aspek psikologis siswa. Tugas diberikan tanpa henti, kesibukan siswa hanya untuk memenuhi target capaian pembelajaran tujuan jangka pendek.

Berdasarkan hasil pra-survei di Sekolah Menengah Atas Negeri 1 Kendawangan, meunujukkan proses yang berbeda dari guru Pendidikan Agama Islam. Dari hasil observasi awal dalam pembelajaran Agama Islam terlihat adanya upaya mengintegrasikan nilai-nilai multicultural. Guru berusaha mngembangkan materi pelajaran dengan memberikan kotekstualisasi dalam kehidupan sehari-hari. Keadaan pembelajaran baik di dalam kelas maupun kegiatan yang bersifat

${ }^{4}$ Ismail Sukardi, "Character Education Based on Religious Values: An Islamic Perspective," Ta dib, 2016, https://doi.org/10.19109/td.v21i1.744. 
sementara/insidental disekolah oleh guru PAI menjadi media untuk mentransformasikan nilainilai multicultural sebagaimana keadaan plurlitas di sekolah.

Fakta tersebut di atas jika dilihat dari perspektif sosiologi sangat menarik untuk dikaji, para ahli sosiologi pendidikan, pendidikan senantiasa memberikan reaksi resiprokal (timbal-balik) antara dunia pendidikan dengan kondisi sosial masyarakat. Relasi ini bermakna bahwa apa yang berlangsung dalam dunia pendidikan merupakan gambaran dari kondisi yang sesungguhnya di dalam kehidupan masyarakat yang kompleks.

Berdasarkan pada penjelasan di atas maka tulisan ini bertujuan untuk memberikan penjelasan secara detil tentang kontribusi guru PAI dalam menginternalisasikan nilai-nilai multicultural di lingkungan sekolah yang dilakukan secara terintegrasi dalam berbagai bentuk kegiatan. Hal ini berbeda dengan sekolah lain, sehingga menarik untuk dikaji dan dipublikasikan agar menjadi contoh bagi sekolah yang akan mengembangkan budaya multikultur di lingkungan sekolahnya.

\section{Kerangka Teoritik \\ Pengertian Pendidikan Multikultural}

Secara etimologis multikultural terdiri atas dua kata, multi yang berarti banyak, sedangkan culture yang berarti kebudayaan. Jadi, Multikultural merupakan sebagai keanekaragaman budaya, yang merespon atau mengajarkan tentang penghargaan atas sesama. Kata kultur diartikan oleh Clifford Geertz adalah sebuah cara yang dipakai semua anggota dalam sebuah kelompok masyarakat untuk memahami siapa diri mereka dan memberi arti pada kehidupan mereka. ${ }^{5}$ dan lihat ${ }^{6}$.

Istilah multikultur sepadang dengan makana kata plural, Istilah plural mengandung

\footnotetext{
${ }^{5}$ Sulalah Sulalah, "Peran Keluarga, Sekolah, Dan Masyarakat Dalam Pembentukan Karakter Berkualitas," MADRASAH, 2012, https://doi.org/10.18860/jt.v1i1.1855.

${ }^{6}$ Donny Gahral Adian, "Reasoning in a Multicultural Society," Wacana Vol. 13 No. 2 October 2011 13, no. 2007 (2011): 352-64.
}

arti yang berjenis-jenis, oleh karena pluralisme bukan berarti hanya sekedar pengakuan adanya suatu yang berjenis, namun pengakuan yang memiliki implikasiimplikasi politis, sosial dan ekonomi. Maka dari itu, pluralisme bersangkutan dengan prinsip-prinsip demokrasi.

Paradigma multikultural secara implisit juga menjadi salah satu point dari Pasal 4 UU N0. 20 Tahun 2003 Sistem Pendidikan Nasional. Dalam pasal itu dijelaskan, bahwa pendidikan diselenggarakan secara demokratis, tidak diskriminatif dengan menjunjung tinggi Hak Asasi Manusia (HAM), nilai keagamaan, nilai kultural dan kemajemukan bangsa. .

Multikultural adalah konsep yang lahir dari sebuah refleksi dalam suatu kelompok. Isu-isu yang diangkat oleh multkultural adalah macam ras, suku, kelas sosial, gender, ketidakmampuan, perbedaan usia, dan berbagai macam bahasa. Munculnya isu-isu ini dikarenakan sebuah refleksi dari kondisi masyarakat yang mengalami ketimpangan. Multikultural berarti institusional dari keanekaragaman kebudayaan yang dimiliki oleh kelompok-kelompok di dalam bidang-bidang hukum, pendidikan, kebijakan pemerintah, kesehatan, praktekpraktek keagamaan dan bidang lainnya. ${ }^{8}$

Konsep Islam tentang pendidikan dapat dilihat dari makana tarbiyah, yang memilki arti menjaga, memelihara, menanamkan, mengembangkan, melestarikan. Jadi dalam konteks tersebut kajian ini dilakukani. Dengan demikian pendidikan multicultural yang dimaksud adalah upaya menanamkan atau menginternalisasikan nilai-nilai multukultural (keragaman) dengan cara menghormati dan menghargai keragaman yang didesain secara sistematis, terstruktur dan terencana secara matang dan dilakukan secara demokratis di sekolah. ${ }^{9}$.

${ }^{7}$ Kemendikbud, "UU Sisdiknas 2003," KEMENDIKBUD, 2003.value orientation and risk preference

${ }^{8}$ Ma'mun Mu'min, "Pendidikan Islam Multikultural Dalam Perspektif Filosofis," FENOMENA, 2016, https:// doi.org/10.21093/fj.v8i1.487.

${ }^{9}$ Abdullah Aly, "Studi Deskriptif Tentang NilaiNilai Multikultural Dalam Pendidikan Di Pondok 
Dalam literature lain disebutkan bahwa, pendidikan multikultural sendiri dapat didefinisikan sebagai pendidikan tentang keragaman kebudayaan dalam merespon perubahan demografis dan kultural lingkungan masyarakat tertentu bahkan dunia secara keseluruhan. Pendidikan multikultural merupakan suatu pendekatan progresif untuk melakukan transformasi pendidikan untuk mengurai segala kekurangan, kegagalan, dan praktik-praktik diskriminasi dalam proses pendidikan. Pendidikan multikultural merupakan respon terhadap perkembangan keragaman populasi sekolah sebagaimana tuntutan persamaan hak bagi setiap kelompok. Pendidikan multikultural juga diakui sebagai pengembangan kurikulum pendidikan untuk memasuki berbagai pandangan, sejarah, prestasi, dan perhatian terhadap orang-orang dari etnis lain. ${ }^{10}$

Sementara Rosyada memberikan pandangan bahwa pendidikan multikultural adalah "proses pengembangan seluruh potensi manusia yang menghargai pluralitas dan heterogenitasnya sebagai konsekuensi keragaman budaya, etnis, suku dan aliran agama" atau dengan kata lain, pendidikan multikultural adalah "proses peserta didik mampu menerima perbedaan, kritik, dan memiliki rasa empati serta toleransi terhadap sesama tanpa memandang golongan, status, gender, dan kemampuan akadimis". ${ }^{11}$

Dari uraian pengertian tentang pendidikan multikultural di atas dapat disimpulkan bahwa pendidikan multkultural adalah suatu proses usaha sadar yang diberikan kepada peserta didik agar mampu menghargai, menerima, dan menumbuhkan sikap peduli terhadap

Pesantren Modern Islam Assalaam," Jurnal Ilmiah Pesantren, 2015.

${ }^{10}$ Hasan Baharun and Robiatul Awwaliyah, "Pendidikan Multikultural Dalam Menanggulangi Narasi Islamisme Di Indonesia" Volume 5 N, no. Pendidikan Multikultural (2017): 224-43.

${ }^{11}$ Dede Rosyada, "Pendidikan Multikultural Di Indonesia Sebuah Pandangan Konsepsional," Journal Solo Didktika Vol 1 No 1, no. Penddkan Multikultural (2014): 1-12. adanya perbedaan, kritik, dan memiliki rasa empati serta toleransi terhadap sesama tanpa memandang golongan, status, gender,dan kemampuan akadimis sehingga terciptanya kepribadian yang cerdas dalam menghadapi masalah-masalah keberagaman budaya.

Tujuan utama pendidikan multikultural adalah menanamkan sikap apresiasi, respek, simpati, dan empati terhadap penganut agama dan budaya yang berbeda. Dengan demikian penganut agama dan budaya yang berbeda dapat saling belajar menahan diri dan tidak setuju dengan ketidak-toleranan seperti inkuisisi (pengadilan negara atas sah-tidaknya teologi atau ideologi), perang agama, diskriminasi, dan hegemoni budaya di tengah kultur monolitik dan uniformitas global. ${ }^{12}$ dan ${ }^{13}$ Jadi, untuk mewujudkan kedamaian dalam kehidupan di daerah rawan konflik seperti Kalimantan Barat, internalisasi nilai-nilai seperti saling memahami, saling menghargai, menghilangkan prasangka negatif serta menjunjung tinggi nilai-nilai universal seperti nilai-nilai demokratis sejak dini, merupakan agenda besar untuk segera dilaksanakan di setiap lembaga pendidikan

Adapun dimensi pendidikan multikultural yang perlu diperhatikan menurut Ngainun dan Achmad Sauqi, meliputi: a) The knowledge construction procces. Suatu proses membangun pengetahuan artinya seorang guru membantu peserta didik untuk untuk mengerti, menyelidiki, dan menyusun secara implisit bagaimana asumsi-asumsi kebudayaan, pembatasanpembatasan, perspektif suatu ilmu. b) Content integration. Seorang guru mengintegrasikan berbagai budaya dan kelompok untuk dapat mengintegrasikan konsep mendasar generalisasi dan teori dalam mata pelajaran.

${ }^{12}$ Rustam Ibrahim, “PENDIDIKAN MultikulturAL : Pengertian, Prinsip, Dan Relevansinya Dengan Tujuan Pendidikan Islam," ADDIN, 2013.etnis, suku, dan aliran (agama

${ }^{13}$ Hamid Hamid, "Manajemen Berbasis Sekolah," Al-Khwarizmi: Jurnal Pendidikan Matematika Dan Ilmu Pengetahuan Alam, 2018, https://doi.org/10.24256/ jpmipa.v1i1.86. 
An aquality paedagogy. Seorang guru pandai dalam menyesuaikan metode pengajaran dengan cara belajar peserta didiknya dalam rangka memfasilitasi prestasi akademik peserta didik yang beragam.

Prejudice reduction. Kultur di sekolah yang memberikan kesamaan terhadap perbedaan jenis kelamin, suku dan kelas sosial. Kesesuaian harus dicapai untuk dapat menciptakan kekuatan peserta didik dalam ras, suku dan kelas sosial yang berbeda. ${ }^{14}$.

\section{METODE PENELITIAN}

Penelitian ini dilakukan di Sekolah Menengah Negeri 1 Kendawangan kabupaten Ketapang Kalimantan Barat. Penelitian ini menggunakan pendekatan kulalitatif. Sumber data dalam penelitian ini adalah dua orang guru PAI dan siswa, sementara data sekundernya adalah pimpinan sekolah dan orang tua wali siswa di SMAN 1 Kendawanyan. Data dikumpulkan menggunakan wawancara mendalam bersifat terbuka dan observasi non partisipan di sekolah ketika guru mengajar dan juga perilaku siswa di sekolah. Metode keabsahan data menggunakan triangulasi sumber, yaitu menghubungkan data dengan sumber lain dalam literatur yang relevan. Dan member check, yakni menelusuri informasi dari informan lain yang memiliki hubungan dekat dengan tema penelitian seperti guru PAI dan dari supervisor di sekolah. Analisis data menggunakan metode interaktif yakni melakukan pengumpulan data, penyeleksian, verifikasi, dan penarikan kesimpulan, analisis dilakukan secara bertahap sejak berada dilapangan.

\section{HASIL DAN PEMBAHASAN}

Landasan Guru PAI Menanamkan nilai Multikultural dalam Pembelajaran di SMA N 01 Kendawangan

Berdasarkan hasil observasi dan pengamatan yang telah dilakukan, adapun

\footnotetext{
${ }^{14}$ Ngainun Naim, "Rekonstruksi Nilai-Nilai Pesantren: Ikhtiar Membangun Kesadaran Pluralisme Dalam Era Multikultura," EDUKASI: Jurnal Penelitian Pendidikan Agama Dan Keagamaan, 2017, https://doi. org/10.32729/edukasi.v7i2.195.
}

landasan guru PAI menerapkan pendidikan multikultural di SMA N 01 Kendawangan terdapat lima landasan dalam internalisasi milai mutikultural dalam pembelajaran PAI di sekolah. Untuk lebih jelas dipaparkan dalam tabel 1 .

Dalam melaksanakan tugas sebagai pendidik selain, merujuk pada regulasi yang diatur dalam undang-undang seperti sisdiknas, Undang-undang guru dan dosen perlu juga memperhatikan aspek nonformal yang senantiasa menyertai tugas guru di sekolah. Aspek nonformal seperti budaya dan demografi, dua hal ini akan menjadi factor yang signifikan dalam pelaksanaan pendidikan di sekalah.

Mendidik sungguh pekerjaan yang unik, karena membutuhkan totalitas kemampuan guru dalam menjaankan tugas, unik karena pada tiap prosesnya senantiasa ada saja persiapan mental dan materi yang berbeda walaupun mengajarkan dikelas yang sama. Perbedaan situasi belajar juga perlu menjadi pertmbangan guru dalam mengajar. Di lingkungan masyarakat yang plural tentu saja dimensi budaya, tradisi ikut memberikan pengaruh terhadap kualitas belajar siswa di sekolah. Dengan demkian guru perlu mengkaji secara mendalam unsur budaya masyarakat setempat agar mempu memberikan pendidikan yang sesuai dengan perkembangan budaya didaerahnya.

Kebiasaan atau adat istadat yang berkembang di lingkungan sekolah merupakan bagian penting yang tidak dapat dipisahkan dari pendidikan di sekolah. Niai-nilai yang hidup dalam diri guru dan siswa perlu diadaptasi menjadi sumber nilai dalm proses pendidikan yang bersifat universal di sekolah. Dalam konteks tertentu, budaya lokal seperti budaya lisan, tulisan atau budaya yang ternuat dalam seni tradisional seperti tarian dan arsitektur menjadi media internalisasi secara tidak langsung kepada siswa.

Dalam konteks Indonesia, yang mayoritas penduduknya beragama Islam, sumber nilai akan banyak diambil dari nilai-nilai agama menjadi landasan dalam mengembangkan budya sekolah. Seperti budaya hidup bersih, 
Table 1: Landasan Internalisasi Nilai multikultural

\begin{tabular}{ll}
\hline \multicolumn{1}{c}{ landasan } & \multicolumn{1}{c}{ Uraian } \\
\hline Budaya (adat & Guru dan staf di SMAN 1 Kendawangan memiliki budaya lisan dan cara kerja yang berbeda \\
istiadat) & karena mereka berasal dari adat budaya leluhur yang berbeda. Mereka masih mewarisi adat \\
& $\begin{array}{l}\text { istiadat dari orang tua, maka tampilan dalam berkata-kata dialeknya berbeda. Perbedan ini perlu } \\
\text { dikelola agar tidak menjadi pemicu konflik laaten yang menganggu hubungan kerja antar guru } \\
\text { dan star di sekolah. }\end{array}$ \\
\hline
\end{tabular}

Keragaman Masing-masing guru, staf dan siswa memliki kerifan local dalam kelompok masyarakatnya. Dan budaya kelompok masyarakat tersebut biaanya memiliki kreativitas dalam membangun budaya yang diwujudkan dalam bergam bentuk seperti seni tari, suara, lukisan, kerajinan tangan dan sebagainya. Keragaman ini adalah potensi yang khas dan perlu dilestarikan agar sekolah memiliki kehasan dan sekaligus menjadi keunggulan. Menurut guru PAI keragama ini perlu mendapat perhatian dari semua guru di sekolah.

Etis (suku) Dilihat dari aspek etnis MAN 1 Kendawangan termasuk plural, ada etnis Dayak, Melyu, Jawa, Sunda, Bugis, Cina, dan Batak. Keragaman etnis juga termasuk potensi bagi pengembangan sekolah, karena akan memberikan warna kebinekaan di sekolah sehingga menguatkan nasionalisme warga sekolah. Namun sebaliknya jika tidak dikelola dengan baik perbedaan etnis akan menjadi sumber konflik karena tidak saling menghargai dan menghormati. Suku adalah kodrat, maka tidak ada seoraangpun yang boleh merendahkannya, itu adalah anugerah dari Tuhan (given) yang harus diterima.

Status social $\quad$ Perbedaan status social dikalangan guru dan siswa cukup beragam di sekolah SMAN 1 masyarakat Kendawangan. Guru tentu sudah ada yang memiliki pangkat/golongan yang Pembina IVa atau $\mathrm{b}$, dan ada juga yang baru golongan IIIa atau b. bahkan ada yang berstatus guru kontak atau guru honorer. Tentu saja perbedaan golongan ini berkonsekuansi pada penghasilan masing-masng guru. Selain itu di kalangan orang tua siswa juga ada perbedaan status social ekonomi dan mata pencaharian orang tua mereka. Sswa ada yang berasal dari kalangan orang tua dengan maya pencaharian sebagi nelayan, petani, buruh pabrik, pekebun, pedagang dan pegamai Negeri sipil PNS/ASN. Hal ini jug akan berpengaruh pada tampilan dan gaya hidup siswa di sekolah. Untuk itu guru perlu memberikan pemahaman yang bijak tentang perbedan status sosial siswa agar tidak menjadi penghalang proses pendidikan.

Ras (warna kulit) Setiap oeang memiliki warna kulit yang khas, ini biasanya dipengaruhi oleh faktor genetik dari orang tua, dan juga biasanya dari etnisnya. Ada kulit putih kemerahan, ada yang gelap, ada yang kuning langsat dan hitam pekat. Pada dasarnya bagi orang yang sudah memiliki wawasan tentang genetik tidak menjadi permasalahan. Namun pada kenyataanya pada level siswa, maalah warna kulit masih menjadi bahan buliying di antara siswa. Mereka ada yang tidak berkenan berteman dengan yang kulit gelap dan kurang cantik atau tidak punya tubuh yang tinggi.

Domisili (jarak Keadaan geografis juga menjadi bagian penting untuk dipahami oleh semua anggota masyarakat dan waktu) khususnya warga sekolah guru staf dan siswa. Domisili rumah orang tua yang jauh dari sekolah dan juga ditempuh denganatau melalui jalur air akan berbeda dengan melalui jalur darat. Perbedaan ini terkadang menjadi kendala bagi siswa atau guru untuk dating tepat waktu di sekolah. Jika perbedaan ini tidak dipahami maka akan menjadi persoalan dalam proes pembelajaran.

budaya santun, damai dapat diadaptasi dari ajaran agama Islam dan katolik/protestan, untuk budaya santun biasanya kebiasaan bersalaman dan cium tangan kepada guru diadaptasi dari kebasaan umat islam mencium tangan orang tuanya di rumah. Hal itu mungkin tidak biasa dilakukan oleh siswa yang beragama selain Islam. Namun karena hal itu diyakni membawa usur kebaikan maka semua siswa dianjurkan untuk berskap santun dengan memberikan salam dan mencium tangan gurunya.
Nila budaya yang bersifat positif dan membentuk individu produktif dapat diadaptasi dari agama seperti kejujuran, keadilan, dan tolongmenolong. Pengembangan kegiatan di sekolah dapat dilakukan melalui aksis kegiatan social untuk memberikan bantuan kepada saudaranya yang tertimpa musibah. Dalam ajaran Islam ada istilah infaq dan shadaqah. Siswa di sekolah telah dibiasakan memberikan Infaq dan shadaqah baik terencana maupun incidental. Budaya semacam iru termasuk budaya yang bersifat universal, 
karena hampir setiap agama mengusung nlainilai tersebut, hanya saja secara teknis berbeda dalam mengimplementasikan dalam kehidupan sehari-hari.

Berdasarkan data dari guru PAI budaya produktif telah coba dilakukan disekolah, walau dalam skala kecil seperti membiasakan hidup sehat, cinta lingkungan, digali dari nilai-nilai budaya local yang telah dibiasakan dalam kehidupan sehari-hari guru maupun siswa. Seperti guru memberikan tugas untuk kreatif dalam memenuhi segala alat dan bahan yang digunakan untuk merawat lingkungan seperti sapu lidi, bak sampah, hiasan dinding kelas dibuat oleh siswa secara berkelompok. Kemudian membuat taman dan kebun untuk laboratorium. Semua dilakukan oleh siswa untuk menjaga keindahan dan kenyamanan di lingkungan sekolah.

Pendidikan dengan pendekatan multicultural bukan perkara yang mudah untuk diterapkan di sekolah. Akan ada banyak variabel yang menjadi tantangan dalam pelaksanaanya. Seringkali tantangan itu dating dari internal. Ketidaksetaraan pemahaman tentang arti keberagaman, membuat sebagian orang perpikiran sempit terhadap perbedaan, seperti perbedaan etnis, status social, dan budaya. Percikan konflik internal guru masih muncul, walau tidak diketahui oleh semua orag di sekolah. Persaan tidak diperlakukan adil oleh pimpinan atau teman sejawat, perbedaan status social dan gaya hidup, hal itu yang sering menjadi pemicu konflik nternal. Tentusaja hal ini terjadi tidak terlepas dari pemahaman dan kesadaran masing-masing orang dalam meliat realitas. Ada yang mudah menerima dan ada yang sulit menerima perbedaan, sekalipun itu berasal dari subjektifitas dirinya sendiri.

\section{Internalisasi Nilai-nilai Multikultural dalam Pembelajaran PAI di SMA N 01 kendawangan.}

\section{Kontekstualisasi dan Pengembangan Materi PAI}

Pendidikan multicultural di sekolah perlu didukung dengan beragam sumberdaya, baik sumberdaya manusia maupun sumberdaya material. Dalam konteks tugas dan fungsi guru, pendidikan multikultural ditentukan oleh pendidik. Masing-masing guru perlu menterjemahkan Visi pendidikan multikultural menjadi tindakan nyata di dalam dan luar kelas. Di kelas tugas guru adalah membimbing siswa untuk menjacapai kompetensi yang diharapkan pada mata pelajaran yang disampaikan. Sementara di luar kelas guru menjadi kontrol social dan tauladan.

Salah satu bagian penting untuk mencapai tujuan pembelajaran tersebut adalah materi ajar. Materi pembelajaran menjadi komponen utama, dan dapat diibaratkan sebagai nasi ketika orang akan lunch atau dinner. Oleh katena materi adalam menu utama, maka materi perlu diolah dengan baik sesuai konteks yang ada dilingkungan siswa. Hal ini akan menjadikan proses pembelajaran memiliki makna yang dalam bagi siswa karena merasakan pentingnya substansi pembelajaran tersebut.

Guru PAI di SMAN 1 Kendawangan dalam mengintenalisaskan nilai-nilai multikultural dalam pembelajaran dirancang dengan mengembangkan materinya atau menjadikan materi yang diajarkan itu dikoneksikan dengan praktik kehidupan sehari hari. Pada saat pembelajaran Agama dengan tema "meniti hidup dengan kemuliaan" pembelajaran di kelas $\mathrm{X}$ semester genap. Tema tersebut menyertakan ayat al-Quran dan Hadits. Surat al-Hujarat ayat 12 sebagai landasan dalam pebelajaran dikaji secara kontekstual. Dalam merespon keberagaman di lingkungan sekolah ayat ini sangat tepat untuk dijadikan legitimasi bahwa perbedaan perlu dipahami secara bijak, karena pperbedaan itu keniscayaan. Pesan moral dari ayat tersebut dijelaskan oleh guru sebagai ayat yang paling tepat untuk saling menjaga dan menghormati perbedaan masing-masing individu.

Guru PAI menegaskan bahwa untuk menjaga kedamaian serta kebersamaan, setiap orang harus menjaga pikiran dan perasaan agar tidak berprasangka buruk pada teman atau saudaranya, dan pesan moral yang kedua adalah 
jangan menggunjing saudaranya sendiri. Guru menyampaikan pada siswa bahwa jika kalian membicarakan kejelekan saudara kemudian kalian mendapatkan sesuatu dari membicarakan hal tersebut, sama saja kamu memakan bangkai saudaranya sendiri. Sunguh sangat menjijikan perbuatan demkian. Contoh lain, Jika kalian membocorkan rahasia dari saudara atau teman, demi mendapatkan imbalan uang, kemudian kamu membelanjakan uang itu untuk membeli makanan, maka kalian sama saja makan kotoran saudaranya itu. Dan itu merupakan perbuatan yang sangat buruk, sama saja dengan perilaku binatang yang tidak memiliki perasaan.

Kemudian pada sesi berikutnya guru melanjutkan dengan memberikan penjelasan dengan sandaran Hadits yang diriwayatkan oleh Bukhari-Muslim. Hadits tentang pengendalian diri. Dalam teks hadits itu berbunyi "orang yang perkasa bukanlah orang yang menang dalam perkelahian, tetapi orang yang perkasa adalah orang yang mengendalikan dirinya ketika marah". Pembelajaran demikian menggabarkan pentingnya kontekastualisasi yang sesuai dengan sudut pandang agama Islam, bahwa Islam adalah agama ramatan lil'alamin. ${ }^{15}$

Hadits ini juga dipandang tepat untuk menjaga kedamian dan keselarasan hidup bersama, khususnya ketika seseorang menghadapi beragam perilaku buruk dari orang lain. Dalam pergaulan, siswa sering terjadi ada siswa mengejek kondisi fisik, perbedaan kecerdasan, guru PAI telah memberikan pandangan tentang pentingnya mengendalikan diri, mengontrol emosi, dan mencontohkan peristiwa konflik sara tahun 1999 di Kecamatan Monterado, berawal dari perkelahian pemuda. Karena mereka tidak mampu mengotrol diri ketika diperlakukan oleh orang, maka terjadilah perkelahian yang menyebabkan terbunuhnya pemuda etnis Dayak. Akibat dari lepas Kontrol emosi, maka berakibat konflik yang sangat luas pada saat itu.

${ }^{15}$ Fachri Ali, "Incorporating Values of Moderate Islam for the 21st Century Learners in an EFL Class," Edukasia Islamika, 2018, https://doi.org/10.28918/jei. v3i1.1299.
Selanjutnya pada materi terkait dengan sejarah Islam, guru PAI memberikan tugas kepada siswa untuk menggali khasanah sejarah lokal, seperti peran tokoh dan juga tradisi kuno yang masih dipraktikan oleh masyarakat. Siswa menelusuri infoemasi baik dari buku maupun dari sumber online dengan merambah di google. Namun pada mmateri tentang sejarah tradisi local siswa mengumpulkan data dari orang tua atau tokoh agama setempat. Mereka mmenggali informasi tradiso local dan diperoleh informasi tentang tradisi adat pernikahan yang biasa disebut "bukong" dimana bukong ini adalah orang yang didandani seperti hantu. Berbagai sumber yang mengatakan bahwa tradisi bukong ini berawal dari sebuah kerajaan yang berada di daerah Kendawangan, bukong-bukong tersebut merupakan pengawal-pengawal setia dari raja untuk melindungi raja tersebut dari ancaman yang ada. Sampai sekarang tradisi ini masih terus berlangsung apabila ada anak keturunan raja melaksanakan pernikahan.

Guru juga mengajurkan agar siswa menggali unsur adat budaya yang merupakan akulturasi dari agama. Hal ini dapat memperluas wawasan multikultural siswa agar tidak ada kesalahpahaman dan merasa hanya kelompok sosialnya saja yang memiliki tradisi. Bagi siswa non muslim tradisi umat Islam di Kendawangan sudah tidak asing lagi, kebiasaan selamatan, yasinan, tahlilan ketika ada keluarga yang meninggal dunia sudah menjadi penglihatan yang dapat ditemukan di berbagai kampung. Maka dari itu guru mengingatkan kepada siswa untuk menghargai tradisi sendiri dan tradisi masyarakat yang beda agama, suku dan budaya.

Dari uraian di atas menggambarkan bahwa pendidikan multikultural bagi generasi muda merupakan suatu keharusan. Karena ditangan para pemuda peradaban dan ilmu pengetahuan akan maju dan berkembang, Dengan pengetahuan luas dan sikap apresiatif terhadap keragaman akan terus membuka pikiran dan perasaannya, sensitivitas terhadap isu sara akan selektif dalam membuat keputusan, sehingga terhindar dari konflik social. Sebagai contoh, ketika mereka mampu mengendalikan 
diri dalam keadaan emosi, maka hal-hal buruk tidak akan terjadi, dan sebaliknya mereka akan terus produkti untuk menciptakan hal-hal baik dalam kehidupannya. Dengan memperhatikan penjelasan di atas, maka dapat ditegaskan bahwa peran guru dalam membangun budaya cinta keragaman dalam proses pembelajaran sangat signfikan, bagaimana yang disampaikan oleh Didik bahwa pendidikan agama menjadi pondasi dalam membang kehiduapn yang damai ditengah pluralitas. ${ }^{16}$

Pendidikan multicultural begitu penting untuk dilakukan oleh guru di seluruh tanah air, bagaimanapun sikap intoleran terhadap perbedaan agama, keyakinan dan budaya terus bermunculan meskipun dalam skala kecil, namun demkian akan menjadi ancaman bagi kesatuan bangsa. Lihat saja rilis penelitian yang dilakukan oleh CONVEY Indonesia yang bekerja sama dengan Pusat Pengkajian Islam dan Masyarakat (PPIM) UIN Syarif Hidayatullah Jakarta menunjukkan mayoritas siswa/mahasiswa masih memiliki persepsi intoleran. Survey ini dilakukan di 34 Provinsi di Indonesia pada rentang waktu antara 1 September sampai 7 Oktober 2017 dan melibatkan jumlah total total 2.181 orang: 1.522 siswa, 337 mahasiswa, 264 guru, dan 58 dosen pendidikan agama Islam. Hasil penelitian menunjukkan $51.1 \%$ siswa/mahasiswa cederung memiliki pandangan keagamaan yang intoleran internal sesama pemeluk agama dan $34.3 \%$ memiliki opini intoleran terhadap pemeluk agama lain. Hal ini menunjukkan bahwa siswa SMA dimanapun sangat berpotensi bersikap intoleran jika guru tidak konsisten dalam menanamkan sikap menghargai, menghormati, dan empati terhadap orang lain.

\section{Perluasan Strategi Pembelajaran}

Guru merupakan profesi yang mulia, karena guru merupakan sosok pertama yang megembangkan ilmu-ilmu pengetahuan untuk

${ }^{16}$ Didik Komaidi, "Pendidikan Agama Di Tengah Pluralisme Bangsa (Dari Paradigma Eksklusif Ke Inklusif)," LITERASI (Jurnal Ilmu Pendidikan), 2017, https://doi.org/10.21927/literasi.2014.5(1).79-92. anak. Pernyataan itu menjelaskan bahwa guru tidak dapat dilepaskan dari pendidikan formal dalam mengembangkan potensi jasmani dan ruhani siswa. Selanjutnya dalam konteks pendidikan mutikultural guru diharapkan memliki kemampuan yang memadai. Berdasarkan observasi di sekolah, khususnya guru PAI SMAN 1 Kendawangan, dapat diidenifikasikan bahwa mereka telah menjalankan peran sebagai edukator, fasilitator, dan mulai bergerak berperan menjadi akomodator, dan asimilator. Sebagai edukator dan fasilitator tentu sudah menjadi hal yang biasa dijumpai. Namun peran sebagai akomodator dan asimilator belum semua guru memahaminya.

Ketika guru menjalankan dua peran terakhir itu, guru membutuhan strategi pembelajaran yang lebih banyak dan menarik perhatian siswa. Dar hasil observasi ditemukan bahwa guru telah mencoba utuk melakukan pembelajaran bersifat kolaboratif dimana guru mengajak siswa dalam kelas untuk belajar mengerjakan tugas dikerjakan secara bersama dalam kelompok kecil antara 3-4 siswa. Setelah dikonfirmasi kepada guru dan siswa ditemukan sikap yang termodifikasi seperti siswa mudah bersosialisasi, sikap terbuka dan muncul keberanian untuk berbicara. Melalui metode belajar berkelompok secara tidak langsung siswa akan tumbuh saling menghargai pendapat orang lain, dan juga dapat menjadi media instrospeksi diri karena dapat melihat kemampuan teman-temanya.

Dari uraian di atas memberikan pesan penting bahwa desain pembelajaran harus mendukung terciptanya suasana pembelajaran yang harmonis dan produktif menghasilkan sikap dan nilai baru pada siswa. Karena pendidikan multikultural bukan sekedar level knowledge skill, tetapi mendidik murid menjadi anggota masyarakat yang inklusif, pluralis, demokratis, menghargai empati, serta bersikap adil. Sebagaimana dinyatakan oleh ${ }^{17}$ Untuk

17Miftahur Rohman, "Tinjauan Filosofis Guru Pendidikan Agama Islam Humanis-Multikulturalis STIT Bustanul' Ulum Lampung Tengah," Ta'allum: Jurnal Pendidikan Islam 06 Nomor 1 (2018): 151-74, https:// 
meyokong pendidikan multicultural diperlukan guru dan staf sekolah yang memiliki latar belakang yang beragam.

Desain pembelajaran tersebut termasuk pemelajaran berbasis nilai-nilai sosial multikultural, hal itu akan mengarahkan guru menjadi sosok yang bijak dan akan mengakomodir semua pendapat anak didiknya. Selain itu, akan memahami apa yang dibutuhkan oleh anak didiknya. Kemudian, guru dapat menjadi asimilator karena di suatu kelas bisanya terdiri dari siswa yang berasal dari etnik dan budaya yang beragam. Maka, guru berperan mengelola keragaman yang berpotensi menimbulkan perpecahan. Dengan demikian, asimilasi budaya dapat terjadi dalam lingkungan kelas. Sedangkan fungsi guru sebagai akamodator adalah memfasilitasi semua siswa yang berbeda-beda. Karena peserta didik memiliki kemampuan dan keinginan yang beragam. Bahkan, guru harus dapat memenuhi kebutuhan peserta didik yang berkebutuhan khusus.

Pada kesempatan ini penulis menegaskan bahwa melalui pendidikan Agama Islam yang dikelola secara baik (desain materi dan metode) mampu mengembangkan sikap menerima kemajemukan ekspresi budaya manusia dalam memahami pesan utama agama. Konstruksi pembelajaran semacam ini jelas sekali menuju proses penyadaran yang berwawasan pluralis secara agama, sekaligus berwawasan multikulturalis. Menurut Ngainun Naim dan Achmad Sauqi yang dikutip oleh Miftahur Rohman, pendidikan Islam di sekolah dapat menjadi konstruksi pendidikan Islam yang dapat diposisikan sebagai bagian dari upaya secara komprehensif dan sistematis untuk mencegah dan menanggulangi konflik etnisagama, radikalisme agama, separatisme, dan, disintegrasi bangsa.

\section{Penilaian Berbasis pada Sikap dan Tindakan}

Penilaian pembelajaran merupakan komponen penting dalam Pendidikan. Sehingga

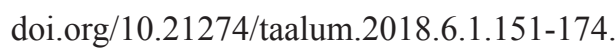

setiap guru melakukan proses penilaian dengan beragam cara dan sasaran capaiannya. Setiap mata pelajaran ada kemungkinan persamaan dan perbedaan karakteristiknya. Begitu juga dengan mata pelajaran Agama Islam tentu ada perbedaan dalam pelaksanaan penilaianya dengan mata pelajaran lainnya

Berdasarkan hasil wawancara dengan bapak Nanang Suryansyah, Rabu 23 Juli 2019). Dapat dipaparkan bahwa dalam kontek semangat multicultural, pada aspek penilaian dilakukan dengan cara memberikan lebih besar bobotnya pada aspek sikap dan perbuatan. Proses penilaian ini telah disampaikan kepada siswa bahwa aspek utama kelulusan pada mata pelajaran Agama Islam adalah aspek sikap dan tindakan kebaikan yang dilakukan selama mengikuti pembelajaran.

Menurut guru sikap atau tindakan nyata adalah totalitas dari pribadi seseorang. Sementara kalua kemampuan mengingat materi pelajaran itu baru tahap awal manusia mengenal kehidupan, dan biasanya belum memiliki makna dalan kehidupannyata. Penilaian sikap dinilai lebih objektif karena mengukur apa yang sudah jelas. Adapun penilaian dengan objektif tes dilakukan untuk mengukur aspek pengetahuan yang bermanfaat untuk memberikan tindak lanjut penguatan sikap siswa baik dalam belajar maupun di luar sekolah. Hal ini ditegaskan dalam amanat kurikulum 2013. Bahwa penilaian sikap awajib dilakukan oleh guru sebagai inti dari pembentukan karakter. ${ }^{18}$.

Penilaian yang dilakukan secara terbuka dan objektif dapat membentuk sikap yang sportif dan saling menghargai perbedaan kemampuan. Orang dikatakan baik bukan karena mereka bayak hafal materi pelajaran atau mereka yang dapat nilai 100 setiap dilakukan tes/ujian. Orang yang baik adalah orang yang mampu memanfaatkan ilmunya untuk kebaikan diri dan lingkungan sekitarnya. Jika seseorang sudah mampu melakukan suatu kebaikan didasarkan

${ }^{18}$ Hari Setiadi, "Pelaksanaan Penilaian Pada Kurikulum 2013," Jurnal Penelitian Dan Evaluasi Pendidikan, 2016, https://doi.org/10.21831/pep. v20i2.7173. 
pada ilmu tentu saja kebaikan itu akan terus menyebar. Namun jika kebaikan itu dilakukan hanya karena insting saja maka kemungkinan besar tidak berulang.

Penilaian sikap merupakan penilaian otentik yang dilakukan oleh guru mata pelajaran. Namun dalam pelaksanaannya penilaian sikap juga melibatkan guru lain seperti guru Bimbingan Konseling. Dengan kolaborasi, penilaian sikap akan semakin valid karena melibatkan sumber lain sebagai pembanding atau penguat terhadap penilaian yang dilakukan oleh guru PAI atau guru maple laiannya ${ }^{19}$

\section{TINDAKAN INSIDENTAL PENGUATAN MULTIKULTUR OLEH GURU PAI DI SEKOLAH \\ Nasihat Dimomentum Upacara Bendara: Internalisasi Sikap Menghormati Dan Positif Thinking.}

Guru memiliki peran yang beragam untuk membentuk kepribadian siswa di sekolah. Pada umumnya pimpinan sekolah sering memberikan fasilitas seperti temapat/ruang (ruang public), waktu, dan materi agar peran sebagai pendidik menjadi lebih luas dan maksimal. Terlebih khusus peran guru dalam membentuk pribadi siswa yang berkarakter. Disini peran dari hidden kurikulum menjadi penting dilakukan, karena guru adalah kurikulum yang bersifat mobile. ${ }^{20}$ Berdasarkan hasil wawancara dengan Guru PAI di SMAN1 Kendawangan bapak Nanang Suryansyah, 23 Juli 2019) didapatkan informasi bahwa guru PAI sering diberikan kesempatan menjadi Pembina Upacara bendera. Kesempatan tersebut menurut pak Nanang Surianyah merupakan kesempatan yang berharga untuk memberikan nasehat pada siswa tentang banyak

\footnotetext{
${ }^{19}$ Wildan Wildan, "Pelaksanaan Penilaian Autentik Aspek Pengetahuan, Sikap Dan Ketertampilan Di Sekolah Atau Madrasdah," Jurnal Tatsqif, 2017, https://doi. org/10.20414/jtq.v15i2.3.

${ }^{20}$ Fathurrohman Fathurrohman, "Konservasi Pendidikan Karakter Islami Dalam Hidden Curriculum Sekolah," Jurnal Pendidikan Agama Islam (Journal of Islamic Education Studies), 2016, https://doi. org/10.15642/pai.2014.2.1.131-143.
}

hal khususnya tentang akhlak/perlaku baik.

Poin utama yang sering disampaiakan oleh Guru PAI dalam kesempatan itu adalah menjaga kebersamaan dan kebebasan antar sesama manusia. Dalam penjelasannya menyatakan bahwa setiap agama yang diyakini oleh seseorang akan membawa kebaikan, maka dari itu guru harus memotivasi siswa agar mempelajari agama secara sungguh-sungguh dan mengamalkan dalam kehidupan sehari-hari. Berikut adalah kutipannya "saya pribadi tidak pernah mengkotak-kotakkan siswa saya, saya mensupport mereka semua, saya beri mereka motivasi untuk taat pada agamanya, karena agama ini kan pilihan mereka masing-masing, tidak boleh dipaksakan kepada siapapun" Nanang Suryansyah, 25 Juli 2019).

Nasihat pamungkas yang sering disampaikan pada momen itu adalah menjaga persatuan dan kesatuan. Guru PAI mengingatkan pada siswa bahwa kemerdekaan bangsa Indonesia diraih atas jasa banyak orang dari berbagai kelompok bukan satu kelompok saja. Begitu juga untuk mengisi dan mempertahankan juga harus dilakukan secara bersama seluruh elemen bangsa dan jangan terpecah belah. Siswa dibimbing untuk menghormati perbedaan dan keragaman di sekolah dan lingkungan sekitarnya. Pembina upacara sering mengingatkan pada siswa agar mengormati para pahlawan nasional, namun juga penting untuk mengingat jasa para tokoh loal (Kalimantan Barat), dengan cara mempelajari, menneladai, dan mengimplementasikan nilainilai tersebut dalam kehidupan sehari-hari. Hal ini diyakini oleh ${ }^{21}$ sebagai cara untuk menguatkan nasionalisme dan cinta pada budaya sendiri serta menguatkan identitas bangsa Indonesia.

Selain itu, poni utama yang tidak kalah penting adalah mengajak siswa untuk selalu perpikiran positif, hindari prasangka buruk,

\footnotetext{
${ }^{21}$ Syaharuddin - Syaharuddin, "Nilai-Nilai Nasionalisme Perjuangan Hassan Basry Sebagai Sumber Belajar Sejarah," Historia: Jurnal Pendidik Dan Peneliti Sejarah, 2019, https://doi.org/10.17509/historia. v2i2.16632.
} 
dan membiasakan untuk mengkonfirmasi atau mengecek kebenaran berita dari seseorang agar tidak salah dalam berbuat yang merugikan diri sendiri dan orang lain. Karena di era digital saat sudah marak orang menggunakan teknologi informasi untuk kepentiangan yang tidak baik seperti, menipu, mengina, memfitnah, bully, dan kejahatan lainnya. Jadi apa yang dilakuakan oleh guru merupakan pembentukan karakter bangsa yang mengerah pada terciptanya generasi kokoh dalam mengadapi era global saat ini ${ }^{22}$.

\section{Jum'at Berkah: Memupuk Sikap Simpatik Melalui Sekolah Bersih dan Sehat}

Pendidikan multicultural dapat dilaksanakan dalam berbagai momentum, baik formal maupun informal. Setiap sekolah akan berbeda-beda dalam mewujudkan harapan dan visinya, inilah keberagaman yang akan menjadi khasanah bangasa untuk mempersiapkan generasi moderat, inklusif dan transformative ${ }^{23}$. Sekolah dapat membuat agenda bersifat tahunan, semester dan perbulan atau perhari untuk menginternalisasikan nilainilai multicultural pada siswa dan seluruh warga sekolah. Di SMAN 1 Kendawangan guru PAI bersama segenap warga sekolah telah menciptakan Susana untuk mmenumbuhkembangkann sikap saling mmenghargai, menghormati dan simpatik pada urusan kebaikan walaupun berhubungan dengan kepemilikan bersifat privat pada kelompok agama tertentu.

Hari jumat dipilih sebagai hari untuk melakukan kebugaran jasmani melalui senam bersama dan dilanjutkan pembersihan lingkungan sekolah. Hal ini merupakan Paradigma sehat, cara pandang membangun kesehatan yang bersifat holistik, proaktif antisipatif, dengan melihat masalah kesehatan sebagai masalah yang dipengaruhi oleh banyak faktor secara dinamis dan lintas sektoral, dalam suatu tempat

${ }^{22}$ Doni Koesoema, Pendidikan Karakter: Strategi Mendidik Anak Di Zaman Global, Jakarta: Grasindo, 2007.

${ }^{23}$ Yoyo Zakaria Ansori, Indra Adi Budiman, and Dede Salim Nahdi, "ISLAM DAN PENDIDIKAN MULTIKULTURAL,” Jurnal Cakrawala Pendas, 2019, https://doi.org/10.31949/jcp.v5i2.1370. yang berorientasikan pada proses peningkatan dan pemeliharaan dan perlindungan terhadap masyarakat agar tetap sehat ${ }^{24}$. Maka dari itu, sekolah memfasilitasi pengembagan sikap universal seperti perduli lingkungan. Setelah senam siswa dikoordinir oleh guru untuk membersihkan beberapa sport seperti halaman sekolah, ruang guru, ruang ibadah (masjid) dan kantor TU. Mereka secara bersama dalam kelompok masing-masing membersihkan tempat itu. Siswa dalam kelompok beragam agama dan etnis, mereka diajarkan untuk bersikap terbuka dan tidak bersikap berdasarkan ideologi agama. Siswa muslim juga bersedia membesihkan tempat ibadah nonmuslim dan sebaliknya. Berikut pernyataan guru pak Andi Lala, 29 Juli 2019.

"Alhamdulilah dalam pembersihan lingkungan semua siswa aktif terlibat dan bagi lingkungan surau, siswa non-muslim mempunyai inisiatif sendiri dan tidak pernah ada paksaan dari pihak sekolah"

Guru merupakan inisiator dari seluruh aktivitas belajar siswa. Sebagaimana data di atas menjelskan bahwa guru adalah miniatur kurikulum sekolah yang bersifat dinamis. Jadi, jelas bahwa untuk melahirkan sikap toleran sangat ditentukan oleh kepribadan guru telah tertanam jiwan pluralis, nasionalis dan moderat dalam beragama. Bagaimanapun sikap dan pola pikir guru sangat berpengaruh pada siswa, guru yang bersikap ekslusif dan intoleran akan berdampak langsung pada sikap dan pola pikir siswa. Jika guru disekolah bersikap inklusif dan toleran maka siswa juga akan bersikap terbuka dan toleran terhadap segala bentuk perbedaan. ${ }^{25}$

\section{Memperkuat Toleransi Dihari Besar Keagamaan}

Di Indonesia termasuk Negara yang paling banyak memperingati hari-hari besar yang mmemiliki arti penting dalam sejarah

\footnotetext{
${ }^{24}$ Febri Endra Budi Setyawan, "PARADIGMA SEHAT," Saintika Medika, 2012, https://doi.org/10.22219/ sm.v6i1.1012.

${ }^{25}$ Miftahur Rohman, "Tinjauan Filosofis Guru Pendidikan Agama Islam Humanis-Multikulturalis STIT Bustanul 'Ulum Lampung Tengah.”
} 
pertumbuhan dan perkembangan bangsa Indonesia. Hari-hari besar di Indonesia sangat beragam latar belakangnya, ada yang berkaitan dengan patriotisme, agama dan budaya nasional/ local, Dan hari-hari bersejarah itu perlu diketahui oleh segenap anak bangsa Indonesia. Salah satu cara anak bangsa mengetahui adalah melakukan peringatan hari-hari besar itu di sekolah.

Sekolah dengan keragaman agama akan lebih dinamis dalam menanamkan nilai-nilai kebinakaan. Di SMAN 1 Kendawangan termasuk sekolah yang warganya beragam agama dan etnis. Maka dari itu pada hari tertentu ada upacara/seremonial peringatan hari besar agama di sekolah. Seperti peringatan Maulid Nabi Muhammad SAW, Isra' Mi'raj, Paskah, Nyepi dan sebagainya. Sekolah memfasilitasi semua agama untuk melakukan seremonial tersebut di sekolah yang terkoordinir secara baik dan berkeadilan.

Di sekolah siswa dan juga guru saling mengormati ketika tiba hari raya masing-masing agama. Mereka saling memberikan ucapan selamat. Begitu juga guru Agama Islam di sekolah juga memberikan ucapan selamat kepada rekan guru dan siswa yang sedang merayakan hari raya tersebut. Banyak ustad/ulama tertentu yang mengharamkan orang Islam memberikan ucapan selamat kepada agama lain. Tapi guru PAI di SMAN 1 Kendawangan memiliki sikap yang moderat, baginya ucapan itu tidak merusak aqidahnya sebagai seorang muslim. Ucapan tersebut dilakukan untuk menghormati dan menyenangkan mereka yang sedang berbahagia. Berikut kutipan wawancaranya, "Selama ini ketika ada hari raya dari agama lain saya selalu mengucapkan selamat kepada siswa saya, karena bagi saya ucapan selamat itu tidak mengganggu akidah, itu hanya sekedar memberikan sedikit kebahagiaan kepada mereka." (wawancara dengan bapak Andi Lala, Senin 29 Juli 2019). Praktik pendidikan yang demikian menjadi sangat relevan dengan kondisi lingkungan belajar yang plural, melalui budaya sekolah nilai toleransi efektif dilakukan dan mampu merubah perilaku saling menghargai. ${ }^{26}$.

${ }^{26}$ Falasipatul Asifa, "Peran Guru PAI Dalam
Khusus guru PAI di sekolah, ketika sedang memperingati hari besar Islam seperti Maulid nabi Muhammad SAW, senantiasa berpesan agar antar siswa di sekolah harus aling menghormati, jangan ada yang melakukan buliying seperti berolo-olok tentang fisik/tubuh dan juga status social seseorang, hal ini disampaikan karena di sekolah siswa yang beragama Islam mencapai $70 \%$ nya. Guru sangat berhati-hati dalam berucap kata apa lagi terkait dengan masalah agama. Karena jika salah berucap baik ketika menjelaskan pelajaran maupun sedang menjadi Pembina upacara akan beragam dampaknya, apalagi jika siswa menerima informasi tidak seperti yang dimaksud oleh guru. Dari data di atas menjelaskan bahwa sikap toleransi bagikan senjata untuk kedamaian dan melahirkan kebersamaan, sebagaimana ${ }^{27}$ telah menegaskan dalam hasil penelitiananya yakni sikap toleransi sangat penting bagi siswa di pondok pesantren modern dan pesantren Salaf.

Berdasarkan informasi dari guru PAI, ternyata siswa selama ini tidak melakukan buliying, hal ini sesuai dengan pernyataan bapak Nanang Suryansyah, Rabu 23 Juli 2019)" Alhamdulillah selama ini belum pernah terjadi pembullian, karena memang pendidikan multikultural ini sangat diterapkan dengan baik oleh pihak sekolah. Pihak sekolah juga memberikan kesetaraan terhadap semua siswanya tidak membeda-bedakan latar belakang baik itu suku dan agamanya selama itu tidak melanggar peraturan yang telah ditetapkan oleh sekolah. Sikap yang dilakukan guru PAI dan segenap warga sekolah tentang tolerasni merupakan implementasi nilai-nilai multikultur. Jadi Pendidikan multicultural buka sekedar mengajarkan tentang pengetahuan keragama, yang utama adalah membentuk sikap empatik

Pengembangan Toleransi Peserta Didik Melalui Budaya Sekolah Di SMA N 8 Yogyakarta," LITERASI (Jurnal Ilmu Pendidikan), 2019, https://doi.org/10.21927/ literasi.2018.9(2).148-155.

${ }^{27}$ Ali Maksum, "Model Pendidikan Toleransi Di Pesantren Modern Dan Salaf," Jurnal Pendidikan Agama Islam (Journal of Islamic Education Studies), 2016, https://doi.org/10.15642/pai.2015.3.1.81-108. 
terhadap perbedaan sehingga semua orang merasa aman, dama dan bahagia ${ }^{28}$.

\section{KESIMPULAN}

Pendidikan multikultural dilakukan oleh Guru PAI di SMAN 1 Kendawangan dengan argumentasi yang kuat yakni a. aspek keragama agama, etnis dan budaya masyarakat kabupaten Ketapang yang sangat potensial dalam dua sisi yaitu kebaikan atau konflik, b. aspek adat budaya local yang perlu dilestarikan dengan saling menghargai dan mebesarkannya di sekolah, c. status social dan ras.

Pendidikan Agama Islam di SMAN 1 Kendawangan memiliki kontribusi yang signifikan dalam internalisasi, penguatan dan pengembagan sikap multikulturalis pada diri siswa yang dilakukan dalam beberapa cara yaitu

(1) integrasi dalam mata pelajaran Agama Islam. Hal ini dilakukan dengan berupaya semaksimal mungkin mengelola pembelajaran yang meliputi: a. mengembangkan dan juga mengkontekstualisasikan konten materi dengan nilai-nilai multukultural (toleran terhadap keragaman agama, etnis, ras, budaya dan status social), b. perluasan strategi pembelajaran seperti pembelajaran kooperatif dan partisipatif, c. penilaian berbasis pada sikap dan perilaku baik yang ditunjukkan dalam kehidupan seharihari di lingkungan sekolah.

(2) kegiatan insidental penguatan multikultural. Dilakukan oleh guru Agama Islam melalui a. menjadi pembina upacara dengan memberikan nasehat pentingnya memperkuat hubungan antar sesama ummat manusia yang dilandasi oleh sikap tolerasi (menghargai, menghormati, jujur, terbuka, cinta tanah air). b, kegiatan jum' at berkah: Memupuk sikap simpatik melalui sekolah bersih dan sehat. Guru PAI mengajak semua siswa untuk saling menjaga kebesihan di tempat ibadah dan lingkungan sekolah setelah olah raga bersama. c. kegiatan perayaan hari-hari besar keagamaan.

${ }^{28}$ Amin Maulani, “Tranformasi Learning Dalam Pendidikan Multikultural Keberagaman," Jurnal Pembangunan Pendidikan: Fondasi Dan Aplikasi, 2013, https://doi.org/10.21831/jppfa.v1i1.1049.
Kegitan perayaan keagamaan di sekolah sebagai media terbangun kebersamaan dan memupuk semangat saling mendoakan.

\section{DAFTAR PUSTAKA}

Abdullah Aly. "Studi Deskriptif Tentang NilaiNilai Multikultural Dalam Pendidikan Di Pondok Pesantren Modern Islam Assalaam." Jurnal Ilmiah Pesantren, 2015.

Adian, Donny Gahral. "Reasoning in a Multicultural Society." Wacana Vol. 13 No. 2 October 2011 13, no. 2007 (2011): 352-64.

Ali, Fachri. "Incorporating Values of Moderate Islam for the 21st Century Learners in an EFL Class." Edukasia Islamika, 2018. https://doi.org/10.28918/jei.v3i1.1299.

Ansori, Yoyo Zakaria, Indra Adi Budiman, and Dede Salim Nahdi. "ISLAM DAN PENDIDIKAN MULTIKULTURAL." Jurnal Cakrawala Pendas, 2019. https:// doi.org/10.31949/jcp.v5i2.1370.

Asifa, Falasipatul. "Peran Guru PAI Dalam Pengembangan Toleransi Peserta Didik Melalui Budaya Sekolah Di SMA N 8 Yogyakarta." LITERASI (Jurnal Ilmu Pendidikan), 2019. https://doi. org/10.21927/literasi.2018.9(2).148-155.

Baharun, Hasan, and Robiatul Awwaliyah. "Pendidikan Multikultural Dalam Menanggulangi Narasi Islamisme Di Indonesia" Volume $5 \mathrm{~N}$, no. Pendidikan Multikultural (2017): 224-43.

Budi Setyawan, Febri Endra. "PARADIGMA SEHAT." Saintika Medika, 2012. https:// doi.org/10.22219/sm.v6i1.1012.

Fathurrohman, Fathurrohman. "Konservasi Pendidikan Karakter Islami Dalam Hidden Curriculum Sekolah." Jurnal Pendidikan Agama Islam (Journal of Islamic Education Studies), 2016. https:// doi.org/10.15642/pai.2014.2.1.131-143.

Hamid, Hamid. "Manajemen Berbasis Sekolah." Al-Khwarizmi: Jurnal Pendidikan Matematika Dan Ilmu Pengetahuan Alam, 2018. https://doi.org/10.24256/jpmipa. v1i1.86. 
Ibrahim, Rustam. "PENDIDIKAN MULTIKULTURAL : Pengertian, Prinsip , Dan Relevansinya Dengan Tujuan Pendidikan Islam." ADDIN, 2013.

Kemendikbud. "UU Sisdiknas 2003." KEMENDIKBUD, 2003.

Koesoema, Doni. Pendidikan Karakter: Strategi Mendidik Anak Di Zaman Global. Jakarta: Grasindo, 2007.

Komaidi, Didik. "Pendidikan Agama Di Tengah Pluralisme Bangsa (Dari Paradigma Eksklusif Ke Inklusif).” LITERASI (Jurnal Ilmu Pendidikan), 2017. https://doi. org/10.21927/literasi.2014.5(1).79-92.

Maksum, Ali. "Model Pendidikan Toleransi Di Pesantren Modern Dan Salaf." Jurnal Pendidikan Agama Islam (Journal of Islamic Education Studies), 2016. https:// doi.org/10.15642/pai.2015.3.1.81-108.

Maulani, Amin. "Tranformasi Learning Dalam Pendidikan Multikultural Keberagaman." Jurnal Pembangunan Pendidikan: Fondasi Dan Aplikasi, 2013. https://doi. org/10.21831/jppfa.v1i1.1049.

Miftahur Rohman. "Tinjauan Filosofis Guru Pendidikan Agama Islam HumanisMultikulturalis STIT Bustanul ' Ulum Lampung Tengah." Ta'allum: Jurnal Pendidikan Islam 06 Nomor 1 (2018): 151-74. https://doi.org/10.21274/ taalum.2018.6.1.151-174.

Mu'min, Ma'mun. "Pendidikan Islam Multikultural Dalam Perspektif Filosofis." FENOMENA, 2016. https:// doi.org/10.21093/fj.v8i1.487.

Naim, Ngainun. "Rekonstruksi Nilai-Nilai Pesantren: Ikhtiar Membangun Kesadaran Pluralisme Dalam Era Multikultura." EDUKASI: Jurnal Penelitian Pendidikan Agama Dan Keagamaan, 2017. https:// doi.org/10.32729/edukasi.v7i2.195.

Rosyada, Dede. "Pendidikan Multikultural Di Indonesia Sebuah Pandangan Konsepsional." Journal Solo Didktika
Vol 1 No 1, no. Penddkan Multikultural (2014): 1-12.

Setiadi, Hari. "Pelaksanaan Penilaian Pada Kurikulum 2013." Jurnal Penelitian Dan Evaluasi Pendidikan, 2016. https://doi. org/10.21831/pep.v20i2.7173.

SISDIKNAS. "SISDIKNAS No.20 Tahun 2003 Tentang Sistem Pendidikan Nasional." Zitteliana, 2003.

Subianto, Jito. "Peran Keluarga, Sekolah, Dan Masyarakat Dalam Pembentukan Karakter Berkualitas." Edukasia : Jurnal Penelitian Pendidikan Islam, 2013. https://doi. org/10.21043/edukasia.v8i2.757.

Sukardi, Ismail. "Character Education Based on Religious Values: An Islamic Perspective." Ta'dib, 2016. https://doi.org/10.19109/ td.v21i1.744.

Sulalah, Sulalah. "Peran Keluarga, Sekolah, Dan Masyarakat Dalam Pembentukan Karakter Berkualitas.” MADRASAH, 2012. https:// doi.org/10.18860/jt.v1i1.1855.

Syaharuddin, Syaharuddin -. "Nilai-Nilai Nasionalisme Perjuangan Hassan Basry Sebagai Sumber Belajar Sejarah." Historia: Jurnal Pendidik Dan Peneliti Sejarah, 2019. https://doi.org/10.17509/ historia.v2i2.16632.

Triandis, H. C., and M. J. Gelfland. "Individualism and Collectivism Scale Culture Orientation Scale." Global and Planetary Change, 2017. https://doi. org/10.1016/j.gloplacha.2017.08.018.

Wildan, Wildan. "Pelaksanaan Penilaian Autentik Aspek Pengetahuan, Sikap Dan Ketertampilan Di Sekolah Atau Madrasdah.” Jurnal Tatsqif, 2017. https:// doi.org/10.20414/jtq.v15i2.3.

Anggirialdi Idafi. 2020. Mengenal Daerahku Kendawangan dan Ketapang. Pontianak: IAIN Pontianak Press.

Https://id.wikipedia.org/wiki/Kabupaten_ Ketapang 